\title{
Persuasion/Dissuasion on National Interest Agenda: A Semiotic Analysis of Pakistani Newspaper Cartoons
}

\author{
Sajid Waqar ${ }^{1}$, Shahida $\mathrm{Naz}^{2} \&$ Mamuna Ghani ${ }^{1}$ \\ ${ }^{1}$ Department of English, The Islamia University of Bahawalpur, Pakistan \\ ${ }^{2}$ Department of Applied Linguistics, Government College University Faisalabad, Pakistan \\ Correspondence: Sajid Waqar, Department of English, The Islamia University of Bahawalpur, Pakistan. E-mail: \\ sajidwaqar20@yahoo.com
}

\author{
Received: January 13, 2020 Accepted: February 20, 2020 Online Published: March 17, 2020 \\ doi:10.5539/ijel.v10n3p68 \\ URL: https://doi.org/10.5539/ijel.v10n3p68
}

\begin{abstract}
The focus of this research was depiction of and persuasion on national interest agenda through semiotics of Pakistani newspapers. It targeted a broad comparison among the semiotics as depicted in two Pakistani English newspapers i.e., Dawn and The Nation. To achieve the objectives, the study was divided into two parts: In part 1 the semiotics were analyzed and in part 2 the written part of political cartoons was analyzed. The study devised an integrated framework of analysis by blending Barthes (1957) theory of semiotics and Fairclough's (1995) 'three dimensional' CDA model for interpretation and explanation of semiotics' discourse. The study revealed the frequent use of multiple persuasion modes in political cartoons of both the newspapers' semiotics and discourse. While comparing the two newspapers' semiotics and discourse, the study also found that daily 'Dawn' semiotics played very negligible role in persuasion on national interest agenda of establishing military courts. However, 'The Nation' semiotics contributed positively towards national interest agenda-setting. The study recommended careful comparison between various newspapers by readership in order to know the ideological bent of newspapers while representing the facts and opinions.
\end{abstract}

Keywords: terrorism, constitutional amendments, military courts, political cartoons, representation, semiotics analysis, CDA, national interest agenda

\section{Introduction}

Since ancient times, political cartoons have proven to be functioning as powerful cultural tools while encompassing viewers of all background. They provide brief, humorous, clever snaps of all types of issues like political, legal, economic and social. According to Willett and Singer (1993), the first recorded political cartoon appeared in Egypt around 1360 BC. Some painter satirized Ikhnaton, the unpopular father-in-law of Tutankhamen. It gave way to numerous satirical attacks on ancient Egyptian leaders that ranged from Cleopatra to low-level government officials (Moyle, 2004). The political cartoon can be defined as a satirical comment (using humor and caricature) about a political person, institution or event reflecting the cartoonist's own values and opinions on that issue. It is, hence, a subjective observation on a political matter (Mateus, 2016). Peculiar background knowledge and analytical skills are needed to comprehend message of cartoons (Lent, 2000). It is pertinent that newspaper cartoons constitute a type of media text who's verbal and graphic features have made them an interesting research field across different academic areas. The cartoons have been selected as object of this study because they provide a format within political communication in which complex messages can be expressed through a single image, wherein, a general extensive clarification is needed when the message is written in words. The political cartoons are characterized by humor, lack of written information and setting of political agenda (Bormann, Koester, \& Bennett, 1978). Next to this, a political cartoon is a format that simplifies the complex political situation and thus helps people to understand current events (Hoffman \& Howard, 2007). Newspaper cartoons are a sketch or comic strip, holding a political or social message that generally narrates to present happenings, typically found on the journalistic side of the newsprint. The political cartoons express opinions, create valuable thoughts and provide precise knowledge on current socio-political issues. Through direct way of communication, cartoons clearly address an issue for general public. Cartoons provide a design within political communication in which intricate messages can be articulated through a single image, whereas usually, an extensive explanation is needed when the message is written in words. Whereas a classic newspaper 
editorial is packed with excessive words to convey information and ideas; a political cartoon reduces a whole article to simple images. McCombs (2004) says that by selecting peculiar news the newspaper editors manipulate readership's attention and perceptions. The capability to affect the importance of topics is usually called the agenda-setting role of the news media by scholars.

This study contends that the newspapers' discourse is ideologically loaded, employs a layered language and plays a significant role in creating public perception on national interest agenda in accordance with ideological bent of editors. Kress (1989) says that language used in press is a matter of choice and not chance. According to Wodak (1996), language is a social semiotics. The print media plays its role in shaping the public perceptions through written and visual discourse. Fairclough (1995) says that discourse is a social practice. Barthes (1957) propounded his theory of semiotics for understanding media language. He contends that semiotics is culturally oriented and has multiple interpretations. In the wake of 9/11 attacks on World Trade Centre (WTC), Pakistan is directly facing war against terrorism. Its armed forces and general public are fighting against terrorists - hiding in Afghanistan and Pakistan. On 16 December 2014, a small group of terrorists managed to enter an Army Public School (APS) in Peshawar Cantonment of Pakistan. The armed terrorists killed over 140 students and teachers and injured scores of innocent victims. While responding, all the State institutions showed their unified stance against the menace of terrorism. It was agreed upon to establish military courts for speedy trial of terrorists - apprehended by the security agencies of the country. For that purpose, certain constitutional amendments were proposed by the legal experts. Therefore, the national interest agenda of constitutional amendments by the parliament of Pakistan gave way to media debates and detailed coverage in headlines, editorials and cartoons. The purpose of this paper is to reveal the role played by newspaper cartoons in setting the national interest agenda, through emphasizing semiotics and phrases, published in leading newspapers of Pakistan. Specifically, the study focuses on the different issues which were published in leading newspapers regarding constitutional amendments, terrorism, politics and security etc. This study also focuses on how newspaper cartoons are used by print media as a national interest agenda — setting tools, during a specific period of time. The resolution of this paper is to elucidate the role played by political cartoons in setting political agenda, through critically analyzing the newspaper discourses and to identify and explain the meaning and importance of images or visual illustrations in representing issues and events as well as social depictions of political figures and prominent defence forces officers in political cartoons. The cartoons, published in the Pakistani prominent newspapers, after the terrorists' attack on Army Public School Peshawar (Henceforth APS Peshawar) wherein over 140 students and teachers lost their lives and many got injured, is the focus of this research. Specifically, two newspapers, daily 'Dawn' and 'The Nation' are selected due to their wide readership. Additionally, the paper demonstrates how political cartoons were ingeniously used for setting political agenda in Pakistani print media discourse in the wake of the unfortunate incident. For the purpose of addressing the research questions, the cartoons were selected from two Pakistani English language newspapers; ' $D A W N$ ' and 'The Nation' that publish editorial cartoons.

\subsection{Significance of Study}

This study has focused on socio cultural, geo political and religious context of Pakistan's security and anti-terrorism drive. Moreover, relations between different elements of State and society have been described. The semiotics is an authentic and expedient way of expressing a lot without saying much. The previous studies in the area have never touched relations between military elite and political government. In addition, the analytical framework used in this study has been integrated by blending Fairclough's (1995) 'three-dimensional' approach with Barthes' (1957) model of semiotics analysis. Data selection has also been carried out from local English language newspapers that address socio-cultural context of Pakistan. It makes this research unique in nature and approach and is likely to contribute positively to existing scholarship.

\subsection{Research Questions}

1) How daily ' $D A W N$ ' played its role in persuasion on national interest agenda-setting through its semiotics, in the wake of terrorist attack on APS Peshawar, Pakistan?

2) How daily 'The Nation' played its role in persuasion on national interest agenda-setting through its semiotics, in the wake of terrorist attack on APS Peshawar, Pakistan?

3) How the persuasion modes of daily ' $D A W N$ ' and 'The Nation', in the wake of terrorist attack on APS Peshawar, Pakistan, differ from each other's? 


\section{Literature Review}

\subsection{Conceptual Definitions}

For the purpose of easy comprehension of the subject matter by the readers, it is deemed necessary to explain certain terminologies and concepts being used in this study.

\subsubsection{Cartoon, Political Cartoon and Caricature}

According to Oxford Advanced Learner's Dictionary, cartoon means 'an amusing drawing in a newspaper or magazine, especially one about politics or events in the news.' A cartoon is a type of drawing, normally in a non-realistic or semi-realistic style. The specific meaning has evolved gradually, but the current usage usually refers to either: an image or series of images intended for satire, caricature, or humor. The concept originated in middle ages, and cartoon was defined as 'a preliminary drawing for a piece of art, such as a painting, fresco, tapestry, or any other painting medium'. In the 19th century, beginning in Punch magazine in 1843, cartoon came to refer-ironically at first - to comical pictures in periodicals and newspapers. In the early 20th century, it started to denote animated films which looked like printed cartoons. A political cartoon, a type of editorial cartoon, is a graphic with caricatures of public figures, expressing the artist's opinion. An artist who writes and draws such images is known as an editorial cartoonist. Political cartoons typically combine artistic skill, hyperbole and satire in order to question authority and draw attention to corruption, political violence and other social evils.

\subsubsection{Persuasion and Persuasion Modes in Political Cartoons}

Rhetoric, the ability or art of persuasion was an effective tool during political debates of classical Greece. The Greek philosopher Aristotle was a blatant supporter of the art of persuasion as according to him the justice and truth could only prevail if the speaker could put across his view point to win a case. He suggested three modes of persuasion. Ethos (credibility); It means character of the speaker should convince the audience either through previous reputation or through tone, style and views expressed in message. Logos (reason); It refers to the clarity of the message's claim, its logic, and the effectiveness of its supporting evidence. The audience should be able to follow a clear progression of concepts backed up with reasonable and appropriate details. Pathos (emotion); It is often associated with emotions, is more broadly an appeal that draws upon the audience's emotions, sympathies, interests, and/or imagination. There are certain widely agreed upon modes used by the cartoonists for persuasion of readership. Symbolism; Using simple objects to represent ideas, concepts or people is called symbolism in political cartoons, Exaggeration; Overdoing the physical characteristics of a person or thing in order to make a point means exaggeration, Labeling; Labeling objects or people to make it clear what they stand for is termed as labeling and analogy; Comparing two unlike things or comparing complex issues to more simple and common matters is termed as analogy. Irony; shows the difference between appearance and reality or expectations. Satire is a literary device used to ridicule any person, thought or situation. Historically, according to Townsend et al. (2008), political satire roots back to political cartoons itself. In 18th century, English print media would often criticize British rule.

\subsubsection{Semiotics}

The study of signs and symbol is called semiotics. According to Pierce (1902), sign can be symbolic, linguistic, and artificial or any other thing. He divides signs into three categories; Icon, index and symbols. Saussure (1959) gives the concept of signs, signifier and signified. According to him, the language and signs are arbitrary in nature. Barthes (1957) propounds the concept of levels of signification of signs. His three levels are denotative, connotative and mythical.

\subsubsection{Written and Visual Discourse}

Morgan (2010) says that linguistic and paralinguistic both the parts constitute discourse. The word 'discourse' literally means argument. According to Hovav and Levin (2001), expository discourse is very commonly used type of discourse in academic, legal and press writings. Originally, discourse was associated with written and spoken use of language but with the advancement of natural science in 18th century, scientific knowledge was depicted more through visual images than written codes. Jenks (1995) and Rorty (1979) say that comprehension of the discourse consumers increases through visual representation more than spoken or written discourse. The discourse of print media also relies heavily on visual or semiotic representations of common and hardcore issues. Albers (2007) says that visual image if analyzed while following the techniques of written discourse analysis can be called as visual discourse analysis (VDA). 


\subsubsection{National Interest Agenda}

An underlying, often ideological plan or program, that is, in collective benefit of the nation or country during certain situation and specific time frame is termed as national interest agenda.

\subsubsection{National Action Plan}

In early 2015, Pakistani Government drafted a unified plan to fight against the menace of terrorism. This anti-terrorism campaign gained impetus after the terrorist attack on APS Peshawar. The plan included establishment of military courts through constitutional amendments in Pakistan Army Act.

\subsection{Works Already Done}

Mwetulundila, Rauna and Kangira (2012) explored the use of rhetoric and humor in Dudley's political cartoonsextracted from Namibian newspapers. The descriptive study used qualitative design for semiotic and content analysis of cartoons for rhetoric and humor. Data collection was done by using criteria sampling. The analysis was carried out while relying on Aristotle's rhetorical proofs of persuasion: ethos, pathos and logos along with humor theories of superiority and incongruity. The study revealed that ethos was used for high profile social figures, pathos was used to stir up the emotions of readers so as to gain support for the argument and logos was employed to indicate that the cartoons were based on truth.

Idid and Chang (2012) examined media and public agenda of two major ethnic groups during the 2008 General Elections by employing content analysis and survey tools. The study found that media agenda had no significant rank-order correlation with the public agenda or the important issues raised by Malay, Chinese, and Indian respondents nationwide. The study established that Chinese media agenda had a significant rank-order correlation with the Chinese public agenda, proposing that the newspapers affected among the Chinese readers on what to think about.

Sani et al. (2012) aimed at demonstrating how political cartoons were used as a vehicle of setting social agenda in Nigerian newspapers to reorient and form the public opinion through frequent depictions. Content analysis was used to categorize the themes contained in the cartoons' depictions. Qualitative approach was used to analyze the cartoons through semiotic analysis. The analysis mainly focused the interpretation of the sign system, centered on the connotation and denotation features, in the cartoons. It was found that $80 \%$ of semiotics focused on substantive themes for setting socio political agenda in Nigeria.

Shaikh et al. (2013) was carried out on Pakistani newspaper cartoons while using quanto-qualitative approach for semiotic analysis. The use of political cartoons as communicative tools was studied during election campaign 2013. The persuasion measures adopted by cartoonists for voters were also studied. The research found that all the persuasive techniques such as symbolism, irony, exaggeration, labeling and analogy were frequently employed by Pakistani print media in editorial cartoons.

Sani and Yar'aduwa (2014) investigated construction of satire through visual metaphor in Nigerian newspapers' editorial cartoons for persuading and influencing public opinion. The study used a cognitive perspective of metaphor and semiotic approach for analyzing the cartoons' visual presentations of real-world happenings. The study suggested that visual metaphor was an innovative and thought-provoking rhetoric that strongly appealed to the minds of readers more tersely than its verbal metaphor. The research findings proposed that visual metaphor could be utilized conceptually to create satire as a way of disapproving social, political and economic corruptions to improve social values.

Ashfaq and Adnan (2014) analyzed political cartoons published in mainstream English language newspapers of Pakistan. It aimed at understanding how political cartoons stayed powerful in representing the images of the United States (US). The Barthes's model of semiotic analysis was utilized in analyzing the sample of political cartoons to determine the stance of political cartoonists in the love-hate syndrome of Pak-US relations. It was established that political cartoonists reinforced pre-existing paradigms of anti-Americanism.

Hussain and Li (2016) investigated the use of Pakistani newspaper cartoons as a tool for setting national interest agenda. The study carried out content analysis for classification of themes of cartoons. The qualitative approach was adopted for semiotic analysis of cartoons. The study findings revealed that about $70 \%$ of cartoon themes focused on substantive issues.

Rehman (2018), attempted to discover the image of Islam as depicted by the American media in the scenario of 9/11 attack. The study aimed to analyze selected American media cartoons related with Islam and to disclose what kind of ideologies they promoted about Islam and its followers. For decoding the cartoons, semiotic model of Roland Barthes was used in semiotic analysis for identification of denotation and connotation of Islam phobic 
signs. It was revealed that American media had depicted Islam in an undesirable way, while making a connotative link between Muslims and terrorist actions. A few recommendations concerning the change of established myth about Islam were also made by the researcher.

El-Falaky (2019) evaluated some editorial cartoons selected from Al-Ahram, an Egyptian newspaper, during 2011 and the 2013 Public Revolutions. The study found how visual images were deliberately created to communicate and propagate ideologies, principles and identities in official print media of Egypt. The study relied upon Kress and van Leeuwen (2006) framework of Visual Grammar. The study revealed the political, social, and cultural milieu in Egypt at the time of unrest. The paper demonstrated that through multimodal texts, official newspaper inscribed its political and ideological stances to its audience.

\section{Methodology}

This study is descriptive in nature and qualitative in approach and having a comparative perspective. According to Blaikie (2010), reality is interpreted by the meanings; the people produce and reproduce as routine part of their daily interactions. Reality can, therefore, be accessed according to Myers (2009) only through social constructions such as language and shared meanings. Interpretivistism-based study targets, through the observation and interpretation of such social constructions, to appreciate a phenomenon as it is experienced and made meaningful by human beings (Collins, 2010). To comprehend how newspapers' political cartoons represented and emphasized the APS Peshawar- Pakistan, terrorism attack, national action plan, constitutional amendments and establishment of military courts and how interpretations of such semiotics may contribute to spreading or reinforcing particular agenda, the researchers used the qualitative research approach for semiotics and critical discourse analyses (CDA).

\subsection{Data Collection}

The present research decodes the linguistic and semiotics discourses of political cartoons, published in the Pakistani English- language newspapers (Dawn, The Nation). The purpose is to reveal the hidden ideologies and show how the communicators select and choose the semiotic and verbal resources that disseminate their desired meanings. These newspapers were selected as a sample for the reasons of; wide circulation, maximum educated readership, being old and well-reputed daily newspapers and for publishing political cartoons on daily basis.

\subsection{Sampling}

The data for the present study were selected from the above-mentioned newspapers appearing during 17 December 2014 to 16 March 2015 (three months) by using criteria sampling technique. It is pertinent to mention that national action plan (NAP) was at its peak when Pakistan Army-related cartoons were extracted prior to and after constitutional amendments and establishment of military courts - for speedy trial of terrorists. The role of print media, in this context, was highly important and particularly civil-military relations and their influence on internal security of Pakistan. The selection of the cartoons was driven by the fact that such depictions are highly contextualized.

\subsection{Framework of Analysis}

An integrated framework of analysis was devised by selecting Barthes' (1957) model of semiotics, with its levels of significations and combining it with Fairclough's (1995) three-dimensional model of critical discourse analysis (CDA). Both the models are precisely described in subsequent sub paragraphs.

\subsubsection{Barthes' Model of Semiotics}

He gave a semiotics theory having three levels of signification. According to Barthes semiotic theory, denotative level or primary level is associated with the dictionary, actual, real, literal or denotative meaning of a given word/sign. Connotative level is typically considered as secondary meaning, hence, considered as second level of signification. These are the meanings which vary from speaker/writer to speaker/writer and listener/reader to listener/reader. Mythological level is associated with the culturally flexible concepts such as hospitality, modesty and bravery. At this level, the culturally recognized variables are critiqued and applied within a specific text or genre within the particular culture or context.

\subsubsection{Fairclough's (1995) Critical Discourse Analysis (CDA) Model}

According to him, every communicative event comprises three dimensions:

\section{1) Text (description)}

Linguistic analysis of text such as grammar, vocabulary, lexical choices and syntactic structures are analyzed in this stage. The section of vocabulary mainly deals with the choice of different words; grammar is about the 
grammatical features, which has a close relation with Halliday's systemic-functional grammar (1970) whereas the textual structure part concerns the whole structures of the discourse.

\section{2) Discursive Practice (interpretation)}

It comprises the production and consumption of texts by speakers/writers and readers/listeners. Fairclough (1989) says that 'interpretation is concerned with the relationship between text and interaction with seeing the text as the product of a process of production, and as recourse in the process of interpretation' (p. 26). The factors such as, how editors produce and readers interpret the news discourse, should be taken into account. Therefore, the news source and reporting modes should be considered for exploration in the interpretive stage of news reports (Fairclough, 1995).

\section{3) Social Practice (explanation)}

It corresponds to the dimension 'discourse as social practice', more precisely 'socio-cultural practice'. In this stage, factors such as ideology or power are catered for the purpose of explaining the interaction between socio-cultural context and the production and consumption of texts. Both the processes, of production and of interpretation rely on context (Fairclough, 1992).

\subsection{Limitations and Delimitations of Study}

This study encompasses the semiotics and critical discourse analysis (CDA) of semiotics or political cartoons published in Pakistani English language newspapers. The study is delimited to only two English- language daily newspapers. The regional languages and national language (Urdu) newspapers were not included in the study due to its limited scope. The data pertaining to depiction of military related cartoons of only three months were selected for analysis by the researchers. The opinions of readership, political leaders and legal experts could not be incorporated in the form of focus group discussions due to difficulty in accessibility. However, these would have made the research findings more valid.

\subsection{Scheme of Data Analysis}

The collected data were analyzed by devising an integrated framework by combining Fairclough's (1995) Model of CDA and Barthe's (1957) model of semiotic analysis as depicted in Figure 1.

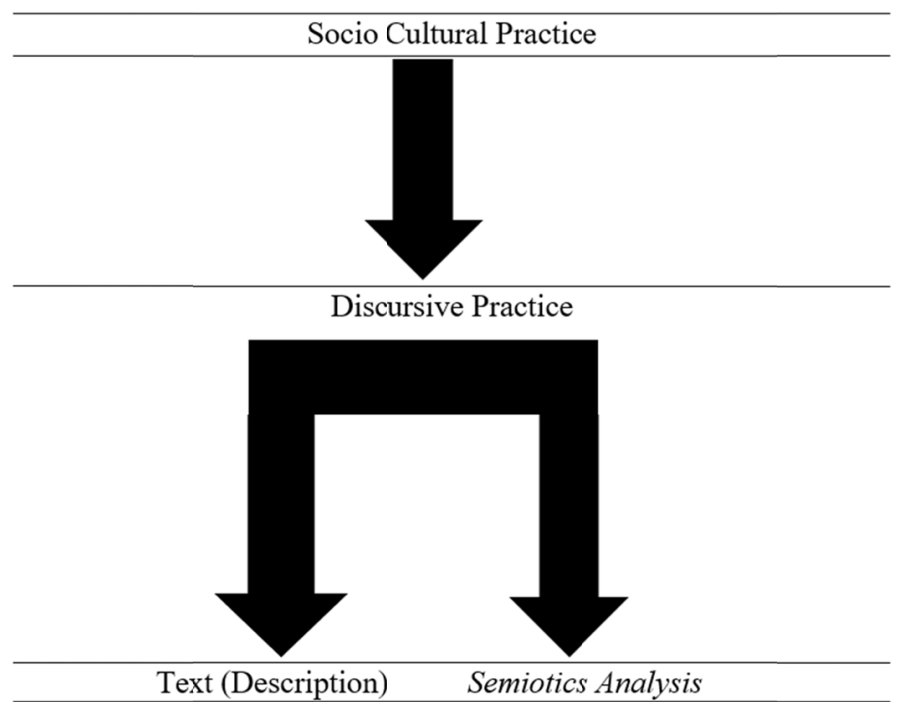

Figure 1. Integrated analytical framework

In the next section, the collected data in the form of text and semiotics are analyzed by using this integrated framework of analysis.

\section{Data Analysis}

Fairclough's (1995) and Barthes' model of Semiotics analysis (1957) i.e., denotation, connotation, and mythological, provide an effective framework for analyzing a stretch of discourse and semiotics in its socio cultural and historical context. The newspaper discourse and semiotics are analyzed by using the integrated framework of analysis as sketched in the preceding section. Fairclough's (1995) 'three-dimensional' analytical 
model is employed in bottom up pattern while integrating Barthes' model of Semiotics analysis (1957) parallel to text analysis part, of Fairclough's (1995) model. The data analysis moves from broader to narrow perspective. Accordingly, socio cultural context is explained first followed by discursive practice and micro analysis of text and semiotics is done at the end.

\subsection{Socio Cultural Practice (Explanation)}

When analyzing the sociocultural practice of a communicative event, the researcher can discover diverse layers such as the immediate situational context, the context of institutional practices the event is enclosed in, or the wider frame of society and culture (Fairclough, 1995). The analysis of sociocultural practice in this study is done by analyzing the relationships; Pakistanis have with terrorism, military, constitution and judiciary.

On the morning of 16 December 1914, a small group of terrorists armed with guns and suicidal jacket entered APS Peshawar in Pakistan and killed over 140 students and teachers and left many as injured. After entering into the war against terrorism since 2001, Pakistan has faced many gun attacks, bomb explosions and suicidal attacks in different towns and cities. Peshawar city has been the main victim of terrorism as it is located closer to Afghanistan where international coalition is fighting against terrorists since two decades. The main targets of terrorists have been government departments, police, military establishments, high profile persons and education institutions. The APS attack was the first heinous and brutal act of its own nature. The attackers were later killed by Pakistan army commandos and identified as Afghanistan based. They had links with Taliban and Al-Qaida network. There has been an era when Pakistan as a State had accepted Taliban- led regime in Afghanistan and had supported Jihad of Taliban against Union of Soviet Socialist Republic (USSR). So, the present relation of Pakistan with Jihad is ambivalent. The 16 December 2014 incident instilled a new spirit of fight against terrorism in all factions of State and society in Pakistan. Speedy trial of terrorists was envisaged to be possible only in military courts. Pakistan has been under three military regimes in the past. The idea of military courts is not new to the nation. For that matter, certain constitutional amendments were needed to provide legal cover to the establishment of military courts. In Pakistan, there have been three constitutions since 1947 and many amendments have been made in the present constitution of 1973. Therefore, the constitutional amendments are also well instilled in socio-political context of Pakistan. The discourses related to terrorism and military courts are well produced by Pakistan media and evenly comprehended by general public of Pakistan.

\subsection{Discursive Practice (Interpretation)}

The processes involved in the production of semiotics discourses by different newspapers in the wake of 16 December 2014 terrorist attack on APS Peshawar are described as discursive practice. The English newspapers selected for analysis are 'The Nation' and 'Dawn'. It has been observed during the study that the same events have been represented in semiotics and discourses differently by the two newspapers. The coverage of 'The Nation' seems pro establishment and in favour of military establishment whereas 'Dawn' semiotics is critical and apprehensive about military's role in National Action Plan (NAP). The persuasion techniques used by the two newspapers on national interest agenda have diverging styles and tones. Due to basic dissimilarity in publication, in viewpoint, style and policy, the semiotics, published by the two newspapers essentially approach the same agenda contrarily. Meanwhile, these differences are not usually obvious when observing word choices and semantics. It has been detected that, despite the expected neutral stance of editors and cartoonists, dictated by professional values such as integrity and objectivity, concealed meanings and philosophies necessarily transpire in the language used to express views on national interest agenda and the persuasion styles of newspaper cartoonists differs from each other's.

\subsection{Text and Semiotics (Description)}

Here, the third component or layer of analysis i.e., semiotics and text of editorial cartoons are analyzed. The samples selected from two different English newspapers are described one by one.

\subsubsection{Dawn (English, Daily) Cartoons}

The semiotics has been collected from two different Pakistani English newspapers. Therefore, for the purpose of simplicity of analysis the two newspapers' visual and linguistic contents are being investigated separately. Likewise, CDA of written contents of semiotics are carried out at the end of every figure's analysis. Five cartoons selected from daily 'Dawn' are being analyzed one by one. 


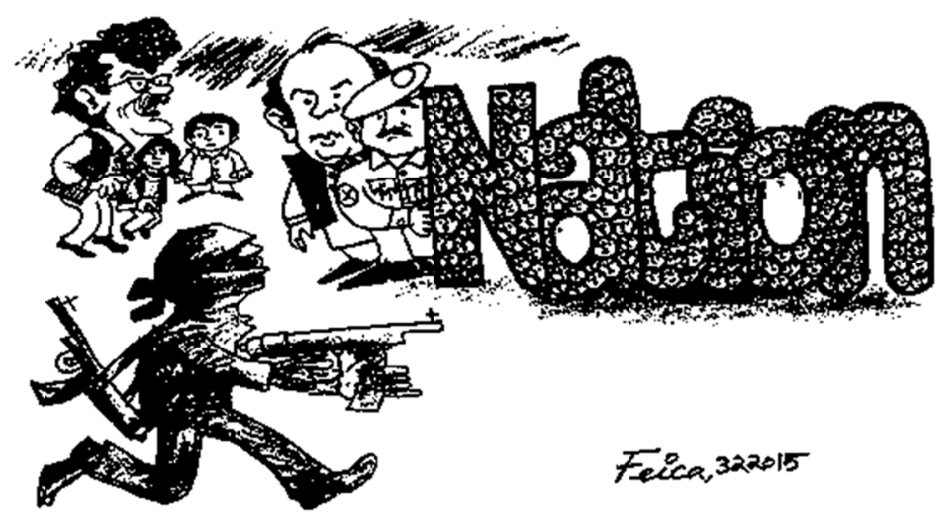

Figure 2. Dawn cartoon

Table 1. Semiotic analysis of Figure 2

\begin{tabular}{|c|c|c|c|}
\hline Sign & Denotation & Connotation & Myth \\
\hline $\begin{array}{l}\text { The word } \\
\text { 'Nation' }\end{array}$ & $\begin{array}{l}\text { A group of people with same language, } \\
\text { culture and history living in a particular } \\
\text { region under single government. }\end{array}$ & $\begin{array}{l}\text { The various parts or segments of } \\
\text { nation standing united together }\end{array}$ & $\begin{array}{l}\text { It means that Pakistani nation is united } \\
\text { in war against terrorism }\end{array}$ \\
\hline Five Persons & $\begin{array}{l}\text { A Pakistani uniform army officer, A } \\
\text { man in Pakistani dress, A man in an } \\
\text { educated teacher's dress and a female } \\
\text { and a male child. }\end{array}$ & $\begin{array}{l}\text { ex COAS General Raheel Sharif and } \\
\text { ex PM Mr. Nawaz Sharif, an } \\
\text { educated man and young children } \\
\text { represent future and hope of the } \\
\text { nation }\end{array}$ & $\begin{array}{l}\text { General Raheel and nation are standing } \\
\text { parallel to each other while Mr. Nawaz } \\
\text { Sharif is seen standing behind the } \\
\text { General. }\end{array}$ \\
\hline Gunman & $\begin{array}{l}\text { An armed gunman who carries two } \\
\text { Guns while he is running and firing } \\
\text { simultaneously }\end{array}$ & $\begin{array}{l}\text { The image of a Taliban terrorist has } \\
\text { been drawn while actively involved } \\
\text { in terrorist attack }\end{array}$ & $\begin{array}{l}\text { It is employed from the cartoon that } \\
\text { Pakistani nation Pakistani government } \\
\text { and Pakistan army are well united } \\
\text { against terrorists }\end{array}$ \\
\hline
\end{tabular}

\section{1) $\mathrm{CDA}$ of Figure 2}

A careful examination of the cartoon figure reveals that the ex- COAS and the Pakistani nation are standing shoulder to shoulder with each other. The ex-Prime Minister is standing behind the COAS and the future and intelligentsia of the nation in the shape of youth and teachers is in a state of chaos. The figure conveys the message to the readership that military top command has assumed the control of the country in the wake of terrorism attack on APS Peshawar. The elected Prime Minister of the country has been depicted while hiding himself behind the COAS. There is an element of satire in the semiotics.

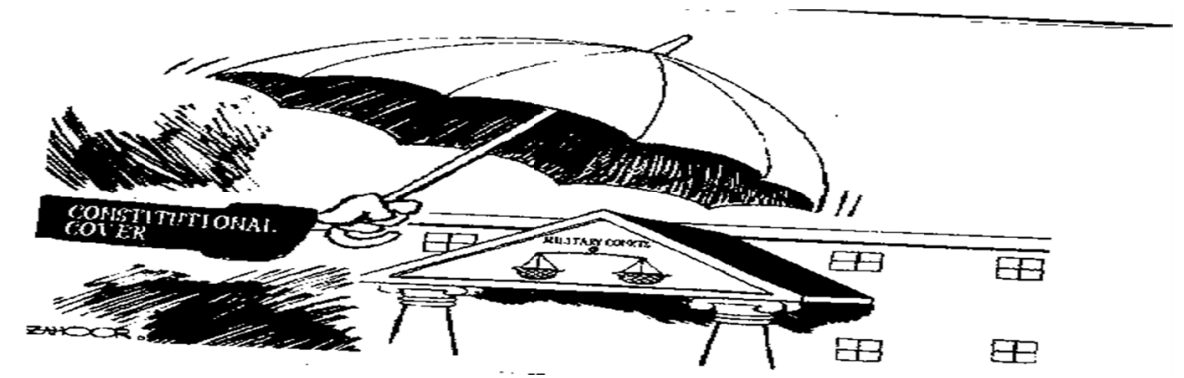

Figure 3. Dawn cartoon 
Table 2. Semiotic analysis of Figure 3

\begin{tabular}{|c|c|c|c|}
\hline Sign & Denotation & Connotation & Myth \\
\hline $\begin{array}{l}\text { Umbrella Human fore arm- } \\
\text { written CONSTITUTIONAL } \\
\text { COVER on it }\end{array}$ & $\begin{array}{l}\text { Held by a man wearing civil } \\
\text { dress and symbolizing cover } \\
\text { and protection from sun, heat } \\
\text { and rain. }\end{array}$ & $\begin{array}{l}\text { Referring to the constitutional } \\
\text { cover being provided to the } \\
\text { establishment of military } \\
\text { courts in Pakistan. }\end{array}$ & $\begin{array}{l}\text { The phrase 'Constitutional } \\
\text { cover' has been used in } \\
\text { negative sense here. It employs } \\
\text { an excuse. }\end{array}$ \\
\hline $\begin{array}{l}\text { Court Building written } \\
\text { MILITARY COURTS on it }\end{array}$ & $\begin{array}{l}\text { Huge court building with icon } \\
\text { of Balance made on front of } \\
\text { porch }\end{array}$ & $\begin{array}{l}\text { The building front having } \\
\text { Western architecture refers to } \\
\text { the military customs of using } \\
\text { colonial force. }\end{array}$ & $\begin{array}{l}\text { Even in the presence of } \\
\text { professional judiciary the } \\
\text { judicial system of the country } \\
\text { will be infringed by military. }\end{array}$ \\
\hline
\end{tabular}

\section{2) CDA of Figure 3}

The phrase 'constitutional cover' has been used in its deeper meaning. According to Oxford Advanced Learner's Dictionary, one meaning of cover is 'to invent a lie or an excuse that will stop somebody from getting into trouble'. The cartoonist is trying to depict that the parliament is providing unnecessary constitutional protection to the establishment of military courts in the country in the presence of well qualified and efficient judiciary. The constitutional amendment being proposed for establishment of military courts for speedy trial of terrorist is just being given a cover by the parliament under pressure of military establishment, where the cases will be decided by use of power rather than justice. In the past the military courts would function to punish anti-military rule elements during military regimes and legal cover used to be acquired from Judiciary. The pair of helmets has replaced the normal pans of balance which depicts revival of military courts established by military regimes in the past However, this time a new experiment of military courts is envisaged under democratic government through constitutional amendment endorsed by elected representatives of the people. Again, the establishment of military courts has been represented in a satirical manner.

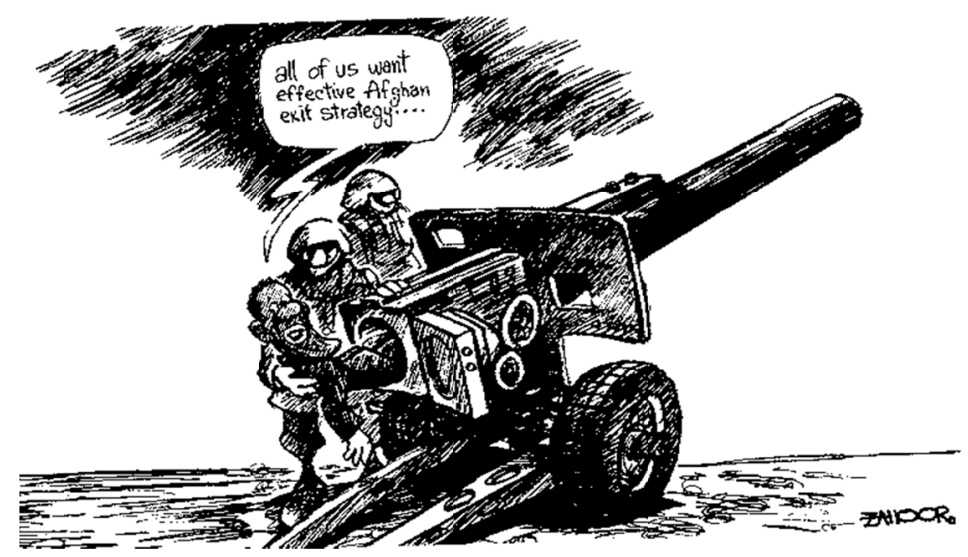

Figure 4. Dawn cartoon

Table 3. Semiotic analysis of Figure 4

\begin{tabular}{llll}
\hline Sign & Denotation & Connotation & Myth \\
\hline Artillery Gun & $\begin{array}{l}\text { Gun in firing position and in } \\
\text { process of loading the shell }\end{array}$ & $\begin{array}{l}\text { Gun symbolizes power and use } \\
\text { of force. }\end{array}$ & $\begin{array}{l}\text { Relating to the united stand of security } \\
\text { forces of Pakistan against terrorism caused } \\
\text { by Taliban }\end{array}$ \\
$\begin{array}{l}\text { Two Army soldiers in } \\
\text { Uniform }\end{array}$ & $\begin{array}{l}\text { Soldiers are Pakistan army } \\
\text { gunners who are wearing } \\
\text { combat dress }\end{array}$ & $\begin{array}{l}\text { State departments of Pakistan } \\
\text { agree upon forceful ouster of } \\
\text { Afghan terrorists hiding in }\end{array}$ & $\begin{array}{l}\text { Representing symbol of national unity and } \\
\text { unified stance of military and civil society } \\
\text { against terrorists }\end{array}$ \\
$\begin{array}{l}\text { One bearded person being } \\
\text { pushed into Gun breach }\end{array}$ & $\begin{array}{l}\text { Bearded man depicts a terrorist } \\
\text { being forcefully pushed into the } \\
\text { gun for throwing him out of } \\
\text { Pakistan. }\end{array}$ & $\begin{array}{l}\text { It symbolizes that all Pakistani } \\
\text { people are well united to throw } \\
\text { out Afghan Taliban who are } \\
\text { involved in terrorist activities. }\end{array}$ & $\begin{array}{l}\text { Unlike past, Pakistani nation supports exit } \\
\text { of Afghan Taliban from Pakistan. }\end{array}$ \\
\hline
\end{tabular}

\section{3) CDA of Figure 4}

Speech bubble or labeling of figure depicts 'all of us want effective Afghan exit strategy'. The clause 
presupposes a united stance of the nation against Afghan refugees' exit from Pakistan. However, there are some political and religious parties and groups that have links with Afghan refugees. But the cartoonist has tried to create the impression that forceful exit of Afghan nationals is a united strategy of Pakistani public and the State. The matter of Afghan refugees' exit from Pakistan has been exaggerated by the cartoonist. So, the exaggeration technique of persuasion has been used by the cartoonist.

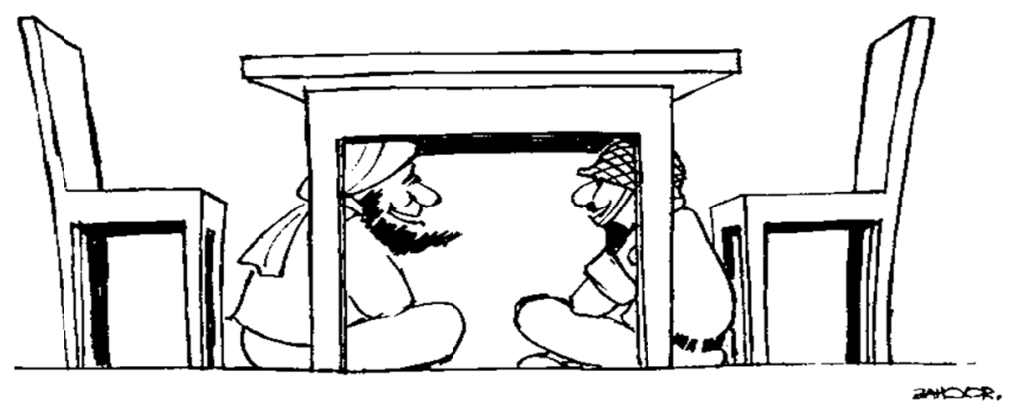

Figure 5. Dawn cartoon

Table 4. Semiotic analysis of Figure 5

\begin{tabular}{llll}
\hline Sign & Denotation & Connotation & Myth \\
\hline Table and Chairs & Two chairs and a table. & $\begin{array}{l}\text { Table and chairs symbolize } \\
\text { bilateral table talks or the formal } \\
\text { meeting between two parties }\end{array}$ & $\begin{array}{l}\text { table and chair represent the bilateral } \\
\text { talks between Pakistan and } \\
\text { Afghanistan in the wake of terrorism } \\
\text { attacks }\end{array}$ \\
$\begin{array}{llll}\text { Man in military uniform } \\
\begin{array}{l}\text { and a beard man with } \\
\text { Turban }\end{array}\end{array}$ & $\begin{array}{l}\text { The dress code of bearded man } \\
\text { indicates that he is an Afghan } \\
\text { leader. Uniform pattern of the } \\
\text { soldier resembles Pakistan land } \\
\text { forces combat dress. }\end{array}$ & $\begin{array}{l}\text { Sitting under the table connotes } \\
\text { backdoor diplomacy between } \\
\text { Afghan government and } \\
\text { Pakistani Amy top leadership. }\end{array}$ & $\begin{array}{l}\text { historical perspective Pakistan's } \\
\text { foreign policy about Afghanistan has } \\
\text { mostly been led by military top brass. }\end{array}$ \\
\hline
\end{tabular}

\section{4) CDA of Figure 5}

Pakistan army remained engaged in Afghanistan from 1979 to 1988 when Union of Soviet Socialist Republics (USSR) had moved its armed forces into Afghanistan. At that time, Pakistan was under Martial Law rule of General Zia. Even after the withdrawal of USSR troops, Pakistan Army has remained directly involved in Afghan policy. There has been a time when Pakistan government not only recognized Taliban led Afghan government but also supported it. In this historical context, Pakistani public believes that it is the Pakistani armed forces and not the government that shape its Afghan policy. The cartoonist has tried to reinforce this public perception. The cartoonist is trying to create the perception that if Afghanistan reconciles with Pakistan it is only possible if Pakistan military elite agrees or endorses. The labeling reads as 'Pakistan supports Afghan reconciliation' is a Pakistan's foreign office statement but its execution has been represented through backdoor diplomacy of Pakistan army. The element of irony and satire has been used by the cartoonist in creating public perceptions.

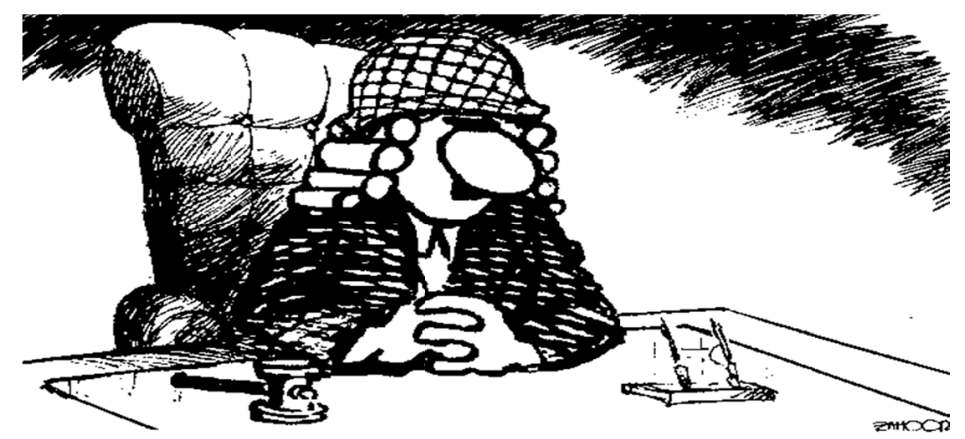

Figure 6. Dawn cartoon 
Table 5. Semiotic analysis of Figure 6

\begin{tabular}{|c|c|c|c|}
\hline Sign & Denotation & Connotation & Myth \\
\hline Table and chair & $\begin{array}{l}\text { Table and chair depicted in the } \\
\text { cartoon symbolize official and } \\
\text { formal setting from their shape } \\
\text { and size }\end{array}$ & $\begin{array}{l}\text { The setting overall represents } \\
\text { the newly established court } \\
\text { room. }\end{array}$ & $\begin{array}{l}\text { In the context of expected } \\
\text { constitutional amendments and } \\
\text { establishment of military courts the } \\
\text { picture connotes the working of new } \\
\text { courts }\end{array}$ \\
\hline Hammer and pens & $\begin{array}{l}\text { Hammer and pen are the items } \\
\text { connected with writing, } \\
\text { summoning and cautioning and } \\
\text { are used in daily routine office } \\
\text { work. }\end{array}$ & $\begin{array}{l}\text { The pen symbolizes scholar and } \\
\text { intellect whereas hammer is } \\
\text { used for forcibly driving of nail } \\
\text { and depicts force and power. }\end{array}$ & $\begin{array}{l}\text { Hammer and pen symbolize the } \\
\text { relation between mind and muscle. }\end{array}$ \\
\hline $\begin{array}{l}\text { Army uniform soldier } \\
\text { Sitting in a chair }\end{array}$ & $\begin{array}{l}\text { An officer of Pakistan army } \\
\text { dressed in combat uniform is } \\
\text { sitting in the courtroom as a } \\
\text { judge. }\end{array}$ & $\begin{array}{l}\text { The dress of the judge is the } \\
\text { combination of military uniform } \\
\text { and close collar. }\end{array}$ & $\begin{array}{l}\text { In the past during military regimes the } \\
\text { military courts functioned. }\end{array}$ \\
\hline
\end{tabular}

\section{5) CDA of Figure 6}

In the historical and socio-cultural context, the semiotics under investigation has deeper and contextualized meaning and significance. Pakistan has been governed by four military rulers in the past. During some military rules, military courts were also established. The speedy trial of the individuals opposing the military governments would be given stern and speedy punishments by the military courts. The cartoonist has tried to create the perception that military courts might be misused for victimizing the opponents of the establishment. The combat helmet is worn over the judicial scarf. The picture connotes combination of chaos and confusion. There is a general perception that such courts did not adhere to proper prosecution and defence laws and rather imposed the decisions. Even, harsh punishments were at times awarded to the people opposing military regimes. The scarf traditionally worn by professional judges has been embedded with gun bullets. Here, the contrast and combination of both has been depicted in the picture. Placing of hammer near right hand and pens on left hand symbolizes preference of force over intellect by the cartoonist. Normally, the military courts are headed by legal experts of the armed forces. However, the 'Dawn' cartoonist has used the device of exaggeration in representation of military courts.

\subsubsection{The Nation (English, Daily) Cartoons}

In this sub section, five semiotics selected from 'The Nation' are analyzed.

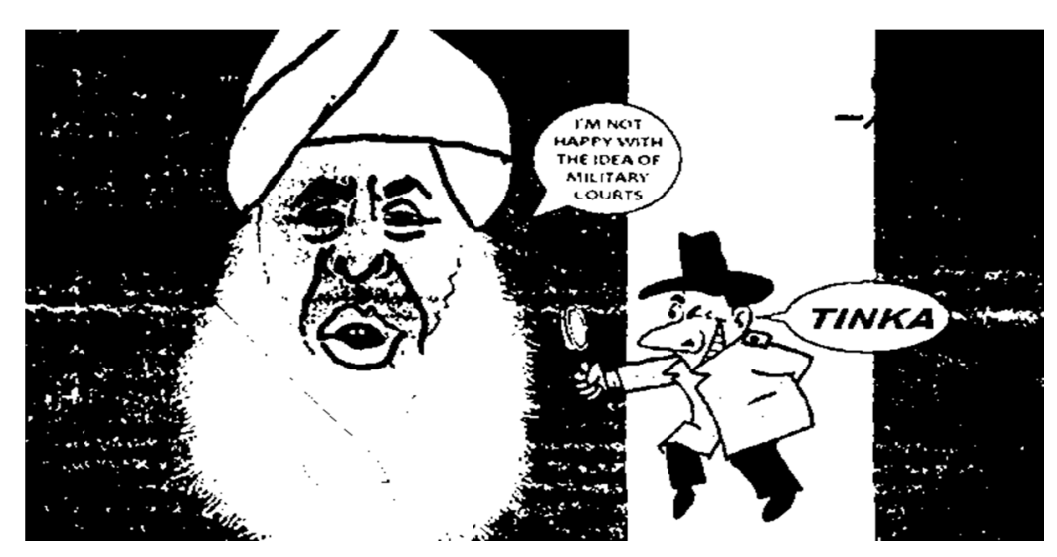

Figure 7. 'The Nation' cartoon 
Table 6. Semiotic analysis of Figure 7

\begin{tabular}{llll}
\hline Sign & Denotation & Connotation & Myth \\
\hline A bearded man with turban & $\begin{array}{l}\text { The main image in the cartoon is } \\
\text { of famous political and religious } \\
\text { personality Maulana }\end{array}$ & $\begin{array}{l}\text { The caricature of Maulana } \\
\text { symbolizes the pro-Taliban }\end{array}$ & $\begin{array}{l}\text { It is generally believed that Taliban } \\
\text { were trained and groomed in }\end{array}$ \\
& The man wearing Western dress & The man in Western dress & Moderassa of Maulana. \\
A man wearing Western & symbon society is \\
dress and holding & is curiously observing the thick & symbolizes moderate faction of & represented to perceive the close \\
magnifying glass. & beard of Maulana with & Pakistani society and of Western & link of Maulana with Taliban. \\
& magnifying glass and search & world. & \\
& straw in his beard. & & \\
&
\end{tabular}

\section{6) CDA of Figure 7}

The frowning face gestures suggest that Maulana is not happy with the idea of military courts. The terrorists involved in anti-State activities will find it hard to escape capital punishment when tried by military courts. The fear of speedy justice is a source of concern for Maulana as portrayed by the cartoonist. Public perception about this matter has been represented here. Maulana Fazal ur Rehman expressed his reservations on establishment of military courts during all parties meeting. So, the cartoonist has represented the perturbed mental state of Maulana in the caricature. The facial expressions of Maulana are full of concern and worry. It seems that the courts are being established to try the cases of his followers. The Urdu language idiom that means ' $a$ straw in thief's beard' has been attributed to Maulana. It implies that Maulana is unhappy over establishment of Military Courts because his trained Taliban and ex-Madrassa students are likely to be tried and convicted by the military courts. Through the use of symbolism, the cartoonist has given the message to the readership that the terrorists who are supported by the political and religious groups of the country could only be punished by the military courts. Hence, the 'symbolism' technique has been used in persuasion over establishing military courts. The support and justification of constitutional amendments and establishment of military courts has been supported by the cartoonist in a covert style.

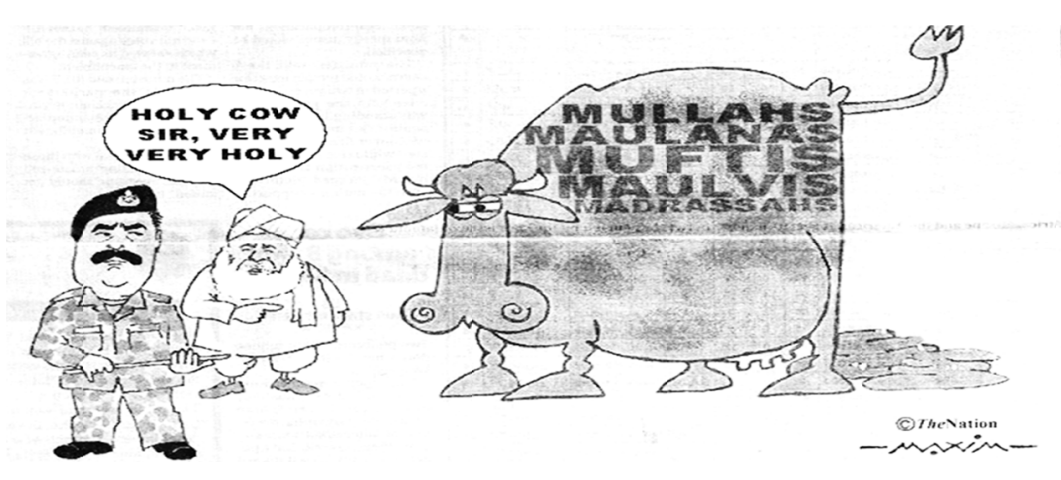

Figure 8. 'The Nation' cartoon

Table 7. Semiotic Analysis of Figure 8

\begin{tabular}{|c|c|c|c|}
\hline Sign & Denotation & Connotation & Myth \\
\hline A uniform soldier & Ex-COAS General Raheel Sharif & $\begin{array}{l}\text { The General symbolizes leading } \\
\text { figure of war against terrorism on } \\
\text { inner front of Pakistan }\end{array}$ & $\begin{array}{l}\text { The General portrayed as leader of war } \\
\text { against terrorism with stick that } \\
\text { symbolizes command. }\end{array}$ \\
\hline $\begin{array}{l}\text { A bearded man with } \\
\text { turban }\end{array}$ & Maulana Fazal ur Rehman & $\begin{array}{l}\text { Maulana symbolizes leaders of } \\
\text { religious groups who support } \\
\text { Jihad particularly Afghan Jihad }\end{array}$ & $\begin{array}{l}\text { Maulana is standing behind the } \\
\text { General and seems to inform him in a } \\
\text { whispering tone about sensitivity of } \\
\text { religious organizations }\end{array}$ \\
\hline Cow & $\begin{array}{l}\text { Cow labeled with MULLAS, } \\
\text { MAULANAS, MUFTIS, } \\
\text { MAULVIS, MADRASSAS }\end{array}$ & $\begin{array}{l}\text { Sensitivity and immunity of } \\
\text { religious persons has been } \\
\text { symbolized by Holy Cow. }\end{array}$ & $\begin{array}{l}\text { Many religions such as Hinduism, } \\
\text { Buddhism and Jainism prohibit cow } \\
\text { slaughter. }\end{array}$ \\
\hline
\end{tabular}




\section{7) CDA of Figure 8}

The phrase 'Holy cow sir, very very holy' has been attributed to Maulana. He has been represented to utter these words about mullas, maulvis, muftis and madrassas. Holy cow is a metaphor used for immune people in Pakistani cultural context. The cow has been depicted with full belly as if pregnant which implies that religious faction will deliver more of its trouble. The wide-open nostrils of cow symbolize her anguish and irritability. The cow is shown throwing dung which implies dirty and undesired activities of so-called religious faction of society. In the past, religious groups were perhaps supported by Pakistani military that's why Maulana seems secretly conversing with the General. Religious organizations were perhaps promoted and supported by security agencies of Pakistan particularly for Afghan and Kashmir Jihad from 1979 to 2001. Some elements probably once supported by security forces, got involved in anti-State activities. Due to such situation, security agencies started exercising restrictions on such Jihad organizations. After establishment of military courts, it could be envisaged by clerics and Jihad commanders that the culprits involved in terrorism activities would be executed indiscriminately by the military courts. Especially, the suspended sentences of capital punishment were likely to be revived by such courts. So, the cartoonist has depicted religious group leaders of Pakistan as above the law. The technique of 'symbolism' has been effectively been used by the cartoonist such as holy cow and labeling used on it. Likewise, dung, of the cow symbolizes the filth and undesired activities of the so-called religious faction of society. The figure has carried the message of support of constitutional amendments targeted at terrorists.

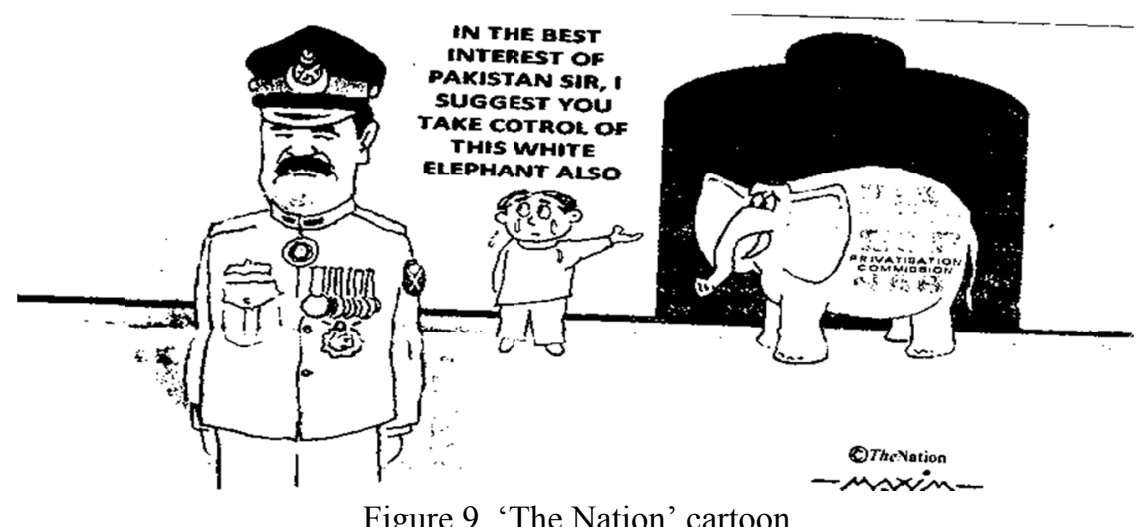

Table 8. Semiotic analysis of Figure 9

\begin{tabular}{|c|c|c|c|}
\hline Sign & Denotation & Connotation & Myth \\
\hline A uniform soldier & $\begin{array}{l}\text { Caricature is of ex-COAS } \\
\text { General Raheel Sharif }\end{array}$ & $\begin{array}{l}\text { It symbolizes military's control } \\
\text { of Pakistan's Governess }\end{array}$ & $\begin{array}{l}\text { In perspective of the cartoon and } \\
\text { Pakistan's historical context it symbolizes } \\
\text { public belief in good governess of military }\end{array}$ \\
\hline A common man & $\begin{array}{l}\text { A common man in poor } \\
\text { economic condition with tears in } \\
\text { his eyes. }\end{array}$ & $\begin{array}{l}\text { The man symbolizes Pakistan } \\
\text { public living below poverty line. }\end{array}$ & $\begin{array}{l}\text { Common man has always attached high } \\
\text { hopes with Pakistani military elite. }\end{array}$ \\
\hline An elephant & $\begin{array}{l}\text { White color elephant having } \\
\text { labeling of PR, PIA, PSM, ECP, } \\
\text { NAB and PRIVATIZATION } \\
\text { COMMISSION }\end{array}$ & $\begin{array}{l}\text { White elephant symbolizes } \\
\text { poorly governed Pakistan and its } \\
\text { profitless organizations }\end{array}$ & $\begin{array}{l}\text { Some past military regimes raised some } \\
\text { departments into profitable organizations. }\end{array}$ \\
\hline
\end{tabular}

\section{8) CDA of Figure 9}

In Pakistan's political context, it is generally believed that governess of military regimes has been better than that of elected governments. The use of adverb 'also' in the phrase 'In the best interest of Pakistan, I suggest you take control of this white elephant also', implies and presupposes that Pakistan army has already taken control of Pakistan's judicial system through establishment of military courts. The cartoonists have tried to create a perception that general public is welcoming enhanced role of military leadership in governmental matters of Pakistan. The departments such as Pakistan Railway, Pakistan International Airlines, Pakistan Steel Mills, National Accountability Bureau and Election Commission of Pakistan have been hinted by the cartoonist as profitless. It is being suggested that economy and administration of the country has worsened during elected 
government's tenure. The desire of common man for uplift of Pakistan has been expressed by the cartoonist. Visual metaphor and symbolism have been used for persuasion on national interest agenda by the cartoonist in support of establishment of military courts.

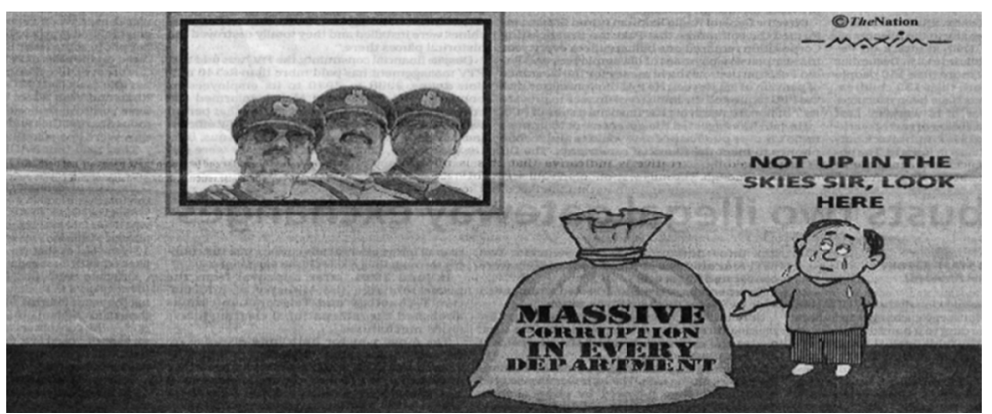

Figure 10. 'The Nation' cartoon

Table 9. Semiotic analysis of Figure 10

\begin{tabular}{llll}
\hline Sign & Denotation & Connotation & Myth \\
\hline $\begin{array}{l}\text { Three uniform } \\
\text { officers }\end{array}$ & $\begin{array}{l}\text { In picture chiefs of Pak Army, } \\
\text { Navy and Air force } \\
\text { have been depicted. }\end{array}$ & $\begin{array}{l}\text { Picture symbolizes top military } \\
\text { leadership. }\end{array}$ & $\begin{array}{l}\text { Looking up in the skies symbolizes } \\
\text { major issues and ignoring common } \\
\text { man's matters. }\end{array}$ \\
$\begin{array}{l}\text { Aepicts a disappointed and } \\
\text { down trodden citizen }\end{array}$ & $\begin{array}{l}\text { Picture symbolizes poor public } \\
\text { of Pakistan }\end{array}$ & $\begin{array}{l}\text { Speech bubbles bear the request of } \\
\text { common man to top military elite for } \\
\text { taking notice of corruption. }\end{array}$ \\
& $\begin{array}{l}\text { Canvas bag with tied top labeled } \\
\text { 'massive corruption in every } \\
\text { department' }\end{array}$ & $\begin{array}{l}\text { Bag symbolizes covered } \\
\text { corruption in government } \\
\text { departments of Pakistan }\end{array}$ & $\begin{array}{l}\text { In perspective the cartoon depicts } \\
\text { common man's expectation to eradicate } \\
\text { corruption }\end{array}$ \\
\hline
\end{tabular}

\section{9) CDA of Figure 10}

The picture of tri services chiefs has been taken while watching the Aircraft show of Pakistan Air force fighter jets on 23 March Parade. They were looking in the sky. The metaphorical representation of the gaze has been depicted as focusing on bigger professional issues. However, common citizen of the country is trying to bring to the notice of military leadership the massive corruption in civil government departments. It implies that the public of Pakistan has a lot of expectations from its armed forces. The general public not only endorses establishment of military courts for speedy trial of terrorists but it also supports more pronounced role of military in assisting civil government in governess. Cartoonist has tried to persuade the readership for accepting military's role and support in governess of the country.

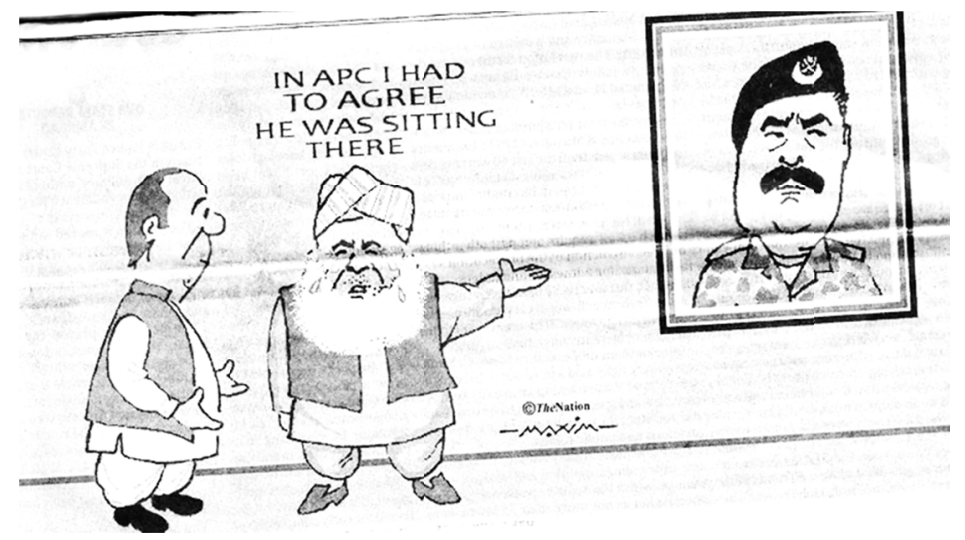

Figure 11. 'The Nation' cartoon 
Table 10. Semiotic analysis of Figure 11

\begin{tabular}{|c|c|c|c|}
\hline Sign & Denotation & Connotation & Myth \\
\hline $\begin{array}{l}\text { A man in Pakistani } \\
\text { national dress }\end{array}$ & $\begin{array}{l}\text { Ex-Prime Minister of Pakistan } \\
\text { Mr. Nawaz Sharif }\end{array}$ & $\begin{array}{l}\text { Prime Minister symbolizes the } \\
\text { Chief Executive or } \\
\text { administrative head of civil } \\
\text { government. }\end{array}$ & $\begin{array}{l}\text { Surprised, confused and indecisive } \\
\text { Prime Minister forming a bridge } \\
\text { between popular will and security } \\
\text { establishment. }\end{array}$ \\
\hline $\begin{array}{l}\text { A bearded man with } \\
\text { turban }\end{array}$ & $\begin{array}{l}\text { Religious political party leader } \\
\text { Maulana Fazal ur Rehman }\end{array}$ & $\begin{array}{l}\text { Maulana symbolizes Jihad } \\
\text { supporting elements of State of } \\
\text { Pakistan }\end{array}$ & $\begin{array}{l}\text { In Pakistan socio cultural context, } \\
\text { it is generally believed that pro } \\
\text { Jihad faction has covert support of } \\
\text { Security agencies. }\end{array}$ \\
\hline Portrait of a soldier & $\begin{array}{l}\text { Portrait is of Ex-COAS General } \\
\text { Raheel Sharif }\end{array}$ & $\begin{array}{l}\text { COAS symbolizes power and } \\
\text { establishment }\end{array}$ & $\begin{array}{l}\text { In Pakistani cultural context it has } \\
\text { been depicted that political parties } \\
\text { agreed to constitutional amendment } \\
\text { under pressure of Pakistan Army }\end{array}$ \\
\hline
\end{tabular}

\section{0) CDA of Figure 11}

At iconic level, the opened hands stand for queries, questions and surprise. The Prime Minister has been represented as full of confusion over agreement of opposition political parties' consensus on establishing military courts. The clause 'In APC I had to agree he was sitting there' has been used as label. All parties' conference (APC) was summoned for deciding about establishing military courts on which all political parties agreed. So, the ruling party and Prime Minster could not offer any resistance to the military command over constitutional amendments and establishment of military courts. The situation left the government with shock and surprise and it perhaps succumbed to the pressure of military command over constitutional amendments and establishment of military courts. Maulana symbolizes pro-Taliban faction of Pakistani society. Here, the cartoon symbolizes moral dominance and physical dominance of armed forces over militant organizations or the underground mutual association of the two.

\section{Findings and Discussion}

This paper has encompassed the main features of visual discourse by selecting political cartoons as sample for the study by applying integrated framework of analysis through combination of Fairclough's (1995) three-dimensional model of CDA and Roland Barthes (1957) semiotic theory of levels of signification i.e., denotation, connotation and myth. Some explicit meanings of the text and visual discourse (cartoons) have been derived by the researchers while applying the model of CDA and semiotic theory i.e., socio-cultural practice, discourse practice, text description, denotation, connotation and myth. By analyzing text and visual discourse in the form of cartoons, the researchers have endeavored to unveil the hidden motive of the cartoonists towards the persuasion on national interest agenda of establishment of military courts for speedy trial of terrorists. The role of military, in national security of Pakistan, forms the main concept of this research. The researchers approached the study through three research questions. The data only related to semiotics about establishment of military courts from two newspapers namely 'The Nation' and 'Dawn' were collected during 17 December 2014 to 16 March 2015 (three months). For the purpose of exploration of semiotics and related text in Pakistani English newspapers, only two newspapers were selected in the study while local languages newspapers, Urdu and remaining English newspapers could not be assimilated due to limited scope of the paper. In the process of deconstruction of hidden themes in newspapers' semiotics and discourse, the researchers took a stand point and therefore do not claim complete objectivity. Researcher's quality is much prominently linked to the results of qualitative study (Morse \& Richards, 2002). The first research question was about the way daily ' $D A W N$ ' played its role in persuasion on national interest agenda-setting through its semiotics. The study revealed that the persuasion techniques such as irony, satire and exaggeration were apprehensively and a bit pejoratively used by the cartoonists in representing the constitutional amendments leading to the establishment of military courts-for speedy trial of terrorists. Seemingly, dissuasion instead of persuasion was resorted to by the daily 'Dawn' over national interest agenda. The second research question was about the manner, the daily 'The Nation' played its role in persuasion on national interest agenda setting, through its semiotics. The data analysis revealed that 'The Nation' semiotics used various persuasion modes like metaphor, irony, symbolism and logic in favour of making constitutional amendments leading to establishment of military courts and speedy trial of terrorists. The third research question was about the difference or comparison between persuasion techniques of daily ' $D A W N$ ' and 'The Nation'. It was brought out in the study that the 'Dawn' semiotics mostly focused on satire while representing civil-military relations in establishment of military courts. The 'Dawn' cartoonists did not play 
much pronounced persuasive role in national interest agenda setting. However, the persuasive modes suggested by Aristotle such as logic, emotion and credibility have been frequently and effectively used by 'The Nation' cartoonists. In addition, through the use of symbolism, metaphor, labeling and satire 'The Nation' cartoonists have displayed their pro military stance. The criteria sampling is an effective method for limited level qualitative studies. However, it might not produce much valid results thereby affecting the generalizability of study findings. The study findings are much aligned with general political and ideological bent of the newspapers selected for sampling. The daily 'The Nation' is thought to be pro-establishment newspaper and daily 'Dawn' is considered as more neutral and serious in its reporting style. After passage of four years, the time has proved the efficacy of military courts in Pakistan. Now, the major wave of terrorism has been controlled by the State. Many convicts have been executed by the military courts. There is a clear decrease in terrorist attacks after functioning of military courts.

\section{Conclusion}

This research focused on the semiotics and discourses of English newspapers of Pakistan in the wake of terrorist attack on APS Peshawar in Pakistan which resulted in killing of over 140 students and children and injuring many innocents. One of its objectives was to compare the semiotics of two newspapers i.e., daily 'Dawn' and daily 'The Nation'. The study had two distinct parts namely semiotics analysis and critical discourse analysis. Qualitative approach was used in this descriptive research. The researchers devised and employed an integrated framework for data analysis by blending Barthes (1957) model of semiotics analysis and Fairclough's (1995) three-dimensional framework for critical discourse analysis (CDA). The findings revealed the use of various persuasion modes used by the cartoonists and editors of two Pakistani English newspapers. Nonetheless, the comparison between persuasion modes of 'Dawn' and 'The Nation' indicated that the semiotics of 'Dawn' did not try much to persuade the readership towards national interest agenda setting. However, 'The Nation' semiotics or political cartoons were in support of persuasion on national interest agenda of establishment of military courts - for speedy trial of terrorists.

\section{Recommendations}

Positive role of media towards national interest agenda-setting contributes significantly in perception building and persuasion. A careful comparison of ideological bent, by newspapers' readers would make them more analytical and critical about different newspapers. It is recommended that all concerned should keep comparing the coverage style of various newspapers before making value judgments on national interest agenda.

\section{References}

Albers, P. (2007, November). Visual discourse analysis: An introduction to the analysis of school-generated visual texts (Vol. 56, pp. 81-95). 56th yearbook of the National Reading Conference. Oak Creek, WI: National Reading Conference.

Barthes, R. (1957). Mythologies (éditions du Seuil, Coll). Points civilisation, Paris.

Blaikie, N., \& Priest, J. (2019). Designing social research: The logic of anticipation. John Wiley \& Sons.

Bormann, E. G., Koester, J., \& Bennett, J. (1978). Political cartoons and salient rhetorical fantasies: An empirical analysis of the 76 presidential campaign. Communications Monographs, 45(4), 317-329. https://doi.org/10.1080/03637757809375977

Collins, H. (2010). Creative Research: The Theory and Practice of Research for the Creative Industries (208 pages).

Eisenhart, C. (2004). Expository Discourse: A Genre-Based Approach to Social Science Research Texts.

El-Falaky, M. S. (2019). Caricaturing Two Revolutions: Multimodal Discourse Analysis of Egyptian Political Cartoons.

Fairclough, N. (2003). Analysing discourse: Textual analysis for social research. Psychology Press. https://doi.org/10.4324/9780203697078

Fairclough, N. (2013). Critical discourse analysis: The critical study of language. Routledge. https://doi.org/10.4324/9781315834368

Halliday, M. A. (1970). Functional diversity in language as seen from a consideration of modality and mood in English. Foundations of Language, 322-361.

Hoffman, D. R., \& Howard, A. D. (2007). Representations of 9-11 in editorial cartoons. PS: Political Science \& Politics, 40(2), 271-274. https://doi.org/10.1017/S1049096507070424 
Hovav, M. R., \& Levin, B. (2001). An event structure account of English resultatives. Language, 766-797. https://doi.org/10.1353/lan.2001.0221

Idid, S. A., \& Chang, P. K. (2012). The media and public agenda among the Malay and Chinese communities during the 2008 Malaysian General Elections. Asian Social Science, 8(5), 107-115. https://doi.org/10.5539/ass.v8n5p107

Kress, G. (1985). Linguistic processes in sociocultural practice. Victoria: Deakin University.

Kress, G. R., \& Van Leeuwen, T. (1996). Reading images: The grammar of visual design. Psychology Press.

Lent, J. A. (2005). Comic Art of the United States Through 2000, Animation and Cartoons: An International Bibliography (No. 12). Greenwood Publishing Group.

Mateus, S. (2016). Political Cartoons as communicative weapons-the hypothesis of the "Double Standard Thesis" in three Portuguese cartoons. Estudos em Comunicação, 23, 195-221. https://doi.org/10.20287/ec.n23.a09

McCombs, M. (2002, June). The agenda-setting role of the mass media in the shaping of public opinion. Mass Media Economics 2002 Conference, London School of Economics. Retrieved from http://sticerd.lse.ac.uk/dps/extra/McCombs. pdf

Morgan, A. (2010). Discourse analysis: An overview for the neophyte researcher. Journal of Health and Social Care Improvement, 1(1), 1-7.

Mwetulundila, R., \& Kangira, J. (2015). An Analysis of Rhetoric and Humour in Dudley's Political Cartoons Published in the Namibian Newspaper in 2012. International Journal of Research, 63.

Peirce, C. S. (1902). Logic as semiotic: The theory of signs (p. 100). Philosophical writings of Peirce.

Rorty, R. (2009). Philosophy and the Mirror of Nature. Princeton University Press. https://doi.org/10.1515/9781400833061

Sani, I. (2014). The use of verbal and visual metaphors in the construction of satire in Nigerian political cartoons. Online Journal of Communication and Media Technologies, 4(2), 147. https://doi.org/10.29333/ojcmt/2471

Sani, I., Abdullah, M. H., Ali, A. M., \& Abdullah, F. S. (2012). Linguistic analysis on the construction of satire in Nigerian political cartoons: The example of newspaper cartoons. Journal of Media and Communication Studies, 4(3), 52. https://doi.org/10.5897/JMCS11.129

Saussure, F. D. (1959). Course in General Linguistics (Ed. Charles Bally, Albert Sechehaye, and Albert Riedlinger, Trans. Wade Baskin, pp. 350-358). New York: Philosophical Library.

Shaikh, N. Z., Tariq, R., \& Saqlain, N. U. S. (2019). Cartoon war.... A political dilemma! A semiotic analysis of political cartoons. Journal of Media Studies, 31(1).

Singer, J. D., \& Willett, J. B. (1993). It's about time: Using discrete-time survival analysis to study duration and the timing of events. Journal of Educational Statistics, 18(2), 155-195. https://doi.org/10.3102/10769986018002155

Townsend, K., McDonald, P., \& Esders, L. (2008). How political satirical cartoons illustrate Australia's work choices debate. Australian Review of Public Affairs, 9(1), 1-26.

\section{Copyrights}

Copyright for this article is retained by the author, with first publication rights granted to the journal.

This is an open-access article distributed under the terms and conditions of the Creative Commons Attribution license (http://creativecommons.org/licenses/by/4.0/). 